\title{
ANALISIS NUMERIK PENGARUH GEOMETRI BURUNG TERHADAP TEKANAN IMPAK PADA KASUS BIRD STRIKE DENGAN SMOOTHED PARTICLE HYDRODYNAMICS (SPH) MODEL
}

\author{
Endah Yuniarti ${ }^{\star}$, Sahril Afandi Sitompul, Budi Aji Warsiyanto \\ Prodi Teknik Penerbangan, Fakultas Teknologi Kedirgantaraan, \\ Universitas Dirgantara Marsekal Suryadarma \\ *Corresponding Author: endah.yuniarti13@gmail.com
}

\begin{abstract}
Abstrak - Penelitian ini mempelajari pengaruh geometri burung terhadap tekanan impak pada kasus tabrak burung, yaitu tekanan hugoniot dan stagnasi. Geometri burung berbentuk capsule atau silinder dengan kedua ujung setengah bola. Geometri disimulasikan dengan rasio L/D yang berbeda yaitu 1,5; 1,7; dan 1,9. Model material burung elastis, plastis, hidrodinamik digunakan pada simulasi. Simulasi model burung dilakukan dengan metode Smooth Particle Hydrodynamics (SPH) pada variasi kecepatan $100 \mathrm{~m} / \mathrm{s}, 200 \mathrm{~m} / \mathrm{s}$, dan $300 \mathrm{~m} / \mathrm{s}$. Hasil simulasi menunjukkan dengan variasi rasio L/D diperoleh nilai tekanan Hugoniot jauh lebih tinggi sekitar 14-25 kali lipat tekanan stagnasi pada $L / D=1.5,12-25$ kali pada $\mathrm{L} / \mathrm{D}=1.7$, dan 11-34 kali pada $\mathrm{L} / \mathrm{D}=1.9$. Tekanan Hugoniot menunjukkan nilai yang meningkat dari L/D 1.5 sampai 1.9 pada kecepatan 100 m/s. Namun, untuk tekanan Hugoniot pada kecepatan 200 $\mathrm{m} / \mathrm{s}$ menunjukkan nilai yang menurun dari L/D 1.5 sampai 1.9. Tekanan stagnasi rasio L/D 1.9 lebih rendah dibandingkan L/D 1.5 dan 1.7 pada kecepatan impak 100 dan 200 m/s.
\end{abstract}

Kata kunci: Tabrak burung, Geometri Burung, Tekanan Impak, Metode Elemen Hingga.

Abstract - This research studies influence of bird geometry on impact pressures during bird strike, namely Hugoniot and Stagnation pressure. Bird geometry is capsule or cylinder with hemisphere end. The geometry is simulated with different $L / D$ ratio, 1.5, 1.7, and 1.9. Elastic-plastic hydrodynamic material model is used in simulation. Bird model simulation are using smooth particle hydrodynamics method and initial velocities are $100 \mathrm{~m} / \mathrm{s}, 200 \mathrm{~m} / \mathrm{s}$, and $300 \mathrm{~m} / \mathrm{s}$. The results show variation of $L / D$ ratio provide Hugoniot pressure 14-25 times higher than stagnation pressure in $L / D=1.5,12-25$ times in $L / D$ $=1.7$, and 11-34 times in $L / D=1.9$. Hugoniot pressures show an increased value from $L / D 1.5$ to 1.9 at a velocity of $100 \mathrm{~m} / \mathrm{s}$. However, for Hugoniot pressure at a velocity $200 \mathrm{~m} / \mathrm{s}$ shows a value that decreases from $L / D$ 1.5 to 1.9. The stagnation pressure ratio of $L / D$ is lower than $L / D 1.5$ and 1.7 at impact velocity 100 and $200 \mathrm{~m} / \mathrm{s}$.

Keywords: Bird Strike, Bird Geometry, Impact Pressure, Finite Element Method.

\section{PENDAHULUAN}

Istilah tabrak burung biasa diartikan sebagai kontak antara kendaraan yang bergerak (biasanya pesawat terbang) dan hewan sejenis unggas yang dapat terbang (biasanya burung atau kelelawar). Akibat kejadian tabrak burung bagi pesawat terbang dapat bervariasi dimulai dari yang paling ringan yaitu noda darah, lekukan atau lubang kecil dalam struktur pesawat, kerusakan bagian dari suatu komponen pesawat atau bahkan kerusakan total pesawat, dimana ini biasanya disebabkan oleh burung yang terhisap ke dalam engine [1].

Fenomena tabrak burung telah menyebabkan banyak kecelakaan yang mengakibatkan kerusakan pesawat dan korban manusia. Namun, akibat tabrak burung bagi industri penerbangan masih dalam batas yang dapat diterima. Hal ini dikarenakan bahwa fenomena tabrak burung yang menyebabkan kematian manusia hanya sekitar satu dalam setiap $10^{9}$ jam terbang [2]. Namun, seiring waktu fenomena tabrak burung terus meningkat. Menurut database yang disediakan oleh 
International Bird Strike Committee, 55 kecelakaan fatal pada pesawat komersil terjadi antara tahun 1912 dan 2009, di mana 108 pesawat rusak dan 277 penumpang tewas. Sedangkan pada penerbangan militer, akibat dari fenomena tabrak burung jarang diketahui, tetapi setidaknya diketahui telah ada 283 kerusakan pesawat, yang menyebabkan 141 kematian antara tahun 1959 dan 1999 dari beberapa negara yang melaporkan fenomena tabrak burung [3]. Menurut basis data FAA, pada tahun 2014, lebih dari $93 \%$ serangan burung tidak menyebabkan kerusakan yang berat. Justru fenomena tabrak burung yang mengakibatkan kerusakan substansial adalah penyebab utama kerugian ekonomi karena biaya perbaikan dan penundaan penerbangan [3]. Diperkirakan bahwa kerugian ekonomi tahunan di AS sekitar $\$ 614$ juta [4]. Kerugian ekonomi tahunan akibat fenomena tabrak burung pada pesawat komersial di seluruh dunia lebih dari $\$ 1,2$ miliar [5].

Oleh karena itu, semakin banyak produsen pesawat terbang, perusahaan penerbangan dan otoritas pemerintah melakukan program penelitian dan pengembangan ( $R \& D$ ) yang canggih untuk mengurangi biaya tahunan, cedera, dan kematian yang diakibatkan dari fenomena tabrak burung. Salah satu cara meminimalisir efek tabrak burung, yaitu program sertifikasi pesawat untuk memastikan integritas pesawat mengenai kekuatan struktur pesawat terhadap tekanan impak akibat dampak kecepatan tinggi sesuai dengan standar sertifikasi internasional [4].

Perancangan struktur yang tahan terhadap tabrak burung awalnya dilakukan dengan metode eksperimen dan analitik agar dapat memprediksi beban dan tekanan impak burung, serta kemungkinan kerusakan atau kegagalan pada beberapa komponen struktur pesawat. Metode eksperimen yang berbiaya besar dan membutuhkan waktu lama menjadi tidak praktis bagi pelaku industri pembuatan pesawat. Beberapa penelitian telah mencoba melakukan pendekatan terhadap permasalahan tabrak burung secara analitik, tetapi metode tersebut memiliki keterbatasan untuk aplikasi geometri yang kompleks dan model material nonlinier sehingga jarang digunakan.

Perkembangan teknologi komputer yang pesat memudahkan untuk mempelajari fenomena tabrak burung secara numerik (komputasi) sehingga dapat dianalisis secara cepat dan efisien. Oleh karena itu, metode numerik dikembangkan dan diaplikasikan sejak tahun 1970-an dengan tujuan optimasi rancangan guna memastikan sertifikasi uji berhasil dilakukan. Pemodelan material burung sering menjadi permasalahan utama pada simulasi numerik tabrak burung. Hal ini karena perilaku material burung yang nonlinier dan kompleksnya geometri ketika terjadi kontak dengan komponen struktur.

Metode numerik yang umum digunakan berbasis metode elemen hingga. Pendekatan simulasi untuk tabrak burung yang dilakukan menggunakan Lagrangian Modeling Method, Eulerian Modeling Method, Arbitrary Lagrangian-Eulerian Method (ALE) dan Smooth Particle Hydrodynamics (SPH) [6].

Penelitian yang mempelajari pengaruh geometri burung terhadap tekanan impak pada kasus tabrak burung, dengan geometri burung berbentuk capsule atau silinder dengan kedua ujung setengah bola pada rasio L/D 1,$4 ; 1,6 ; 1,8$ dan 2 dengan metode Lagrangian pada variasi kecepatan $100 \mathrm{~m} / \mathrm{s}, 200 \mathrm{~m} / \mathrm{s}$ dan $300 \mathrm{~m} / \mathrm{s}$ sudah pernah dilakukan [7]. Hasil simulasi menunjukkan dengan variasi rasio $L / D$ diperoleh nilai tekanan Hugoniot jauh lebih tinggi sekitar 10-19 kali lipat tekanan stagnasi pada $L / D=1,4,8-18$ kali pada $L / D$ $=1,6,9-17$ kali pada $L / D=1,8$ dan 4-16 kali pada $L / D=2$. Nilai tekanan Hugoniot menunjukkan nilai yang lebih rendah pada rasio $L / D$ 1,6 dibanding rasio lainnya pada kecepatan $200 \mathrm{~m} / \mathrm{s}$ dan $300 \mathrm{~m} / \mathrm{s}$ dan tekanan stagnasi lebih tinggi pada rasio $L / D$ 
2 pada kecepatan impak $200 \mathrm{~m} / \mathrm{s}$ dan 300 $\mathrm{m} / \mathrm{s}$ [7]. Kemudian dengan metode simulasi yang sama yaitu Lagrangian, variasi geometri L/D dan kecepatan tumbukan yang sama juga sudah pernah dilakukan simulasi kasus tabrak burung untuk model burung yang berbeda yaitu silinder [8]. Hasil simulasi model burung silinder menunjukkan nilai tekanan Hugoniot jauh lebih tinggi sekitar 35-38 kali lipat tekanan stagnasi pada $L / D=1,4$, 30-47 kali pada $L / D=1,6$, 31-52 kali pada $L / D=1,8$ dan 28-48 kali pada $L / D=2$. Nilai tekanan Hugoniot menunjukkan nilai yang lebih rendah pada rasio L/D 1,4 dan 1,6 dibanding rasio lainnya dan tekanan stagnasi lebih tinggi pada rasio L/D 2 [8].

Tujuan penelitian ini adalah untuk melakukan simulasi numerik pada kasus tabrak burung dengan geometri bentuk silinder kedua ujung setengah bola dan variasi dimensi burung, yaitu L/D 1,5; 1,7; dan 1,9 dengan metode SPH. Simulasi numerik akan menunjukkan respon dinamik model burung pada kecepatan tinggi berupa gaya impak yang dihasilkan oleh tumbukan antara burung dan target. Hasil dari penelitian ini akan dijadikan acuan dalam perancangan komponen struktur pesawat yang rentan pada fenomena tabrak burung. Pemodelan yang sesuai dengan kondisi fisik akan digunakan selanjutnya dalam simulasi tabrak burung pada komponen struktur pesawat yang rentan terhadap kasus tabrak burung, misalnya windshield, radome, engine inlet, dan leading edge. Dengan demikian, proses desain struktur yang tahan terhadap impak dapat dilakukan dengan cepat, akurat, dan efisien.

\section{METODE PENELITIAN}

\subsection{Teori Hidrodinamika}

Teori analitik tentang persamaan Rankine-Hugoniot yang dihubungkan dengan impak pada air dan studi eksperimen kasus tabrak burung sehingga menghasilkan teori fluida secara komprehensif sudah ada sejak tahun 1978 [9]. Gambar 1 menunjukkan empat fase impak dari silinder fluida terhadap rigid wall. Geometri silinder dengan kedua ujung setengah bola memerlukan teori yang lebih lengkap, tetapi pada dasarnya mempunyai perilaku yang sama dengan silinder. Perilaku tumbukan terdiri dari empat tahap: a) sebelum tumbukan, b) initial shock saat tumbukan awal, c) release wave, dan d) aliran deformasi steady. Kurva tekanan tiap saat pada kasus tumbukan antara soft body dan rigid wall ditunjukkan oleh Gambar 2.

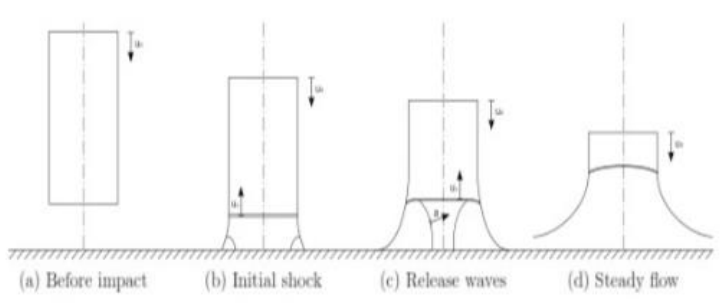

Gambar 1. llustrasi gelombang shock dan release pada tumbukan soft body dengan rigid wall [10].

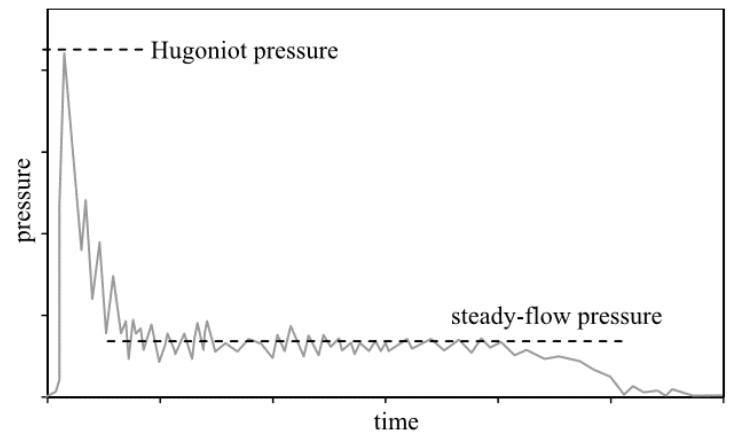

Gambar 2. Kurva tekanan terhadap waktu pada tumbukan soft body dengan rigid wall [6]

Tekanan puncak pada awal tumbukan yang tegak lurus bidang disebut Hugoniot Pressure $\left(P_{H}\right)$.

$$
P_{H}=\rho_{0} u_{0} u_{s}
$$

$\rho_{0}$ adalah massa jenis awal impaktor.

Tekanan stagnasi $\left(P_{s}\right)$ dapat diformulasikan dengan persamaan Bernoulli sebagai berikut:

$$
P_{s}=\frac{1}{2} \rho_{0} u_{0}^{2}
$$

Total durasi (tD) saat tumbukan diperoleh dengan membagi panjang (L) dan kecepatan $\left(\mathrm{u}_{\mathrm{o}}\right)$ sebagi berikut:

$$
t_{D}=\frac{L}{u_{0}}
$$




\subsection{Metode Elemen Hingga Kasus Tabrak Burung}

Pada penelitian ini, metode numerik dengan pemodelan SPH akan dipelajari lebih lanjut. Karakteristik metode $\mathrm{SPH}$ adalah mengubah mesh berupa elemen dan noda menjadi kumpulan partikel. Noda dan elemen pada metode SPH tidak memiliki keterkaitan satu sama lain sehingga memiliki kondisi saling lepas ketika terjadinya pembebanan berupa deformasi.

a) Lagrangian model:

nodes are fixed to the material

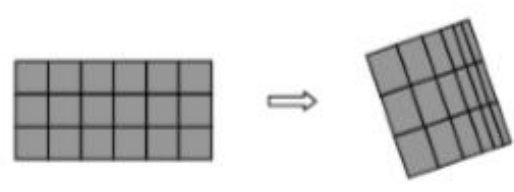

b) Eulerian model:

nodes stay fixed and material flows through the mesh

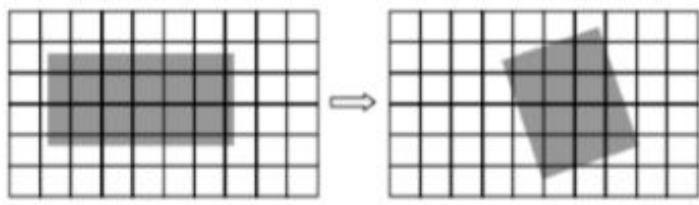

c) ALE model:

Eulerian mesh moves and deforms with material flowing inside

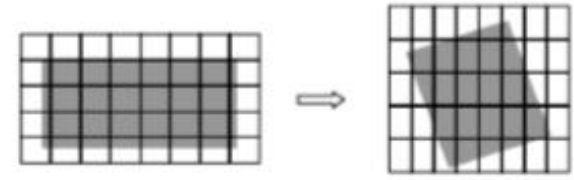

d) SPH model:

fluid is modelled by particles with free motion

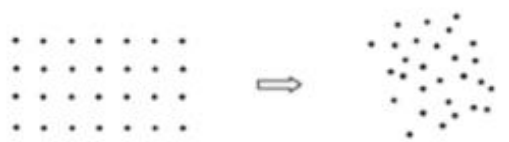

Gambar 3. Pendekatan metode elemen hingga kasus tabrak burung [6]
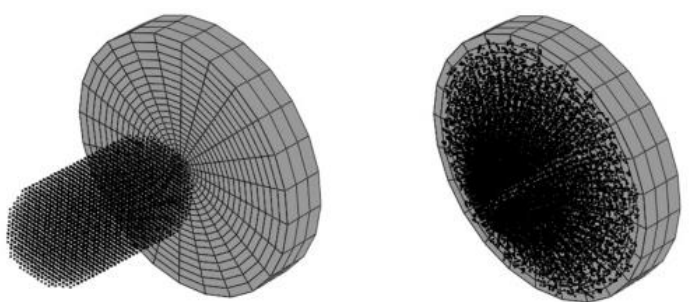

Gambar 4. Simulasi kasus tabrak burung pada rigid plate dengan model impactor SPH [6]

\subsection{Geometri dan Meshing}

Pada simulasi tabrak burung digunakan pemodelan burung dengan definisi rasio dimensi panjang dan diameter seperti ditunjukkan Gambar 5 serta Tabel 1. Pelat dengan ukuran $1 \mathrm{~m} \times 1 \mathrm{~m}$ dipilih agar deformasi burung masih terjadi pada permukaan pelat hingga simulasi berakhir.

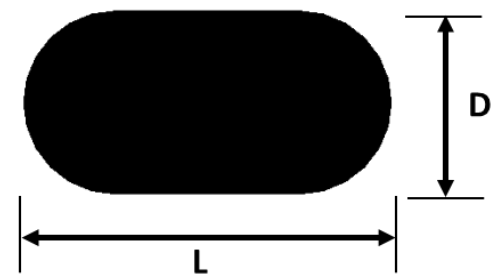

Gambar 5. Definisi geometri model burung

Tabel 1. Variasi Dimensi

\begin{tabular}{|c|c|c|}
\hline $\begin{array}{c}\text { Rasio } \\
(\mathrm{L} / \mathrm{D})\end{array}$ & $\begin{array}{c}\text { Diameter, D } \\
(\mathrm{m})\end{array}$ & $\begin{array}{c}\text { Panjang, L } \\
(\mathrm{m})\end{array}$ \\
\hline 1.5 & 0.128 & 0.193 \\
\hline 1.7 & 0.122 & 0.207 \\
\hline 1.9 & 0.116 & 0.221 \\
\hline
\end{tabular}

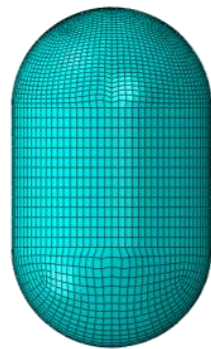

(a)

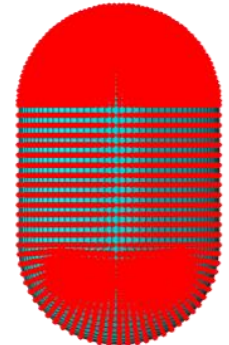

(b)
Gambar 6. Meshing model burung: (a) sebelum dan (b) sesudah dikonversi menjadi partikel

Meshing pada model burung
menggunakan jenis elemen linear hexahedral C3D8R yang selanjutnya dikonversi menjadi partikel seperti ditunjukkan pada Gambar 6. Untuk model pelat, digunakan jenis elemen Shell Quad S4R seperti ditunjukkan pada Gambar 7. Ukuran meshing yang digunakan rata-rata 5 $\mathrm{mm}$. Pengaturan distortion control dan enhanced hourglass control digunakan pada simulasi ini. 


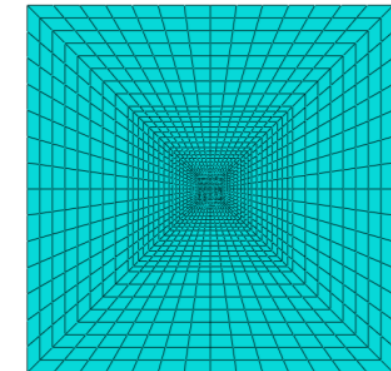

Gambar 7. Meshing model pelat

\subsection{Data Material}

Properti material burung yang digunakan ditunjukkan pada Tabel 2 . Digunakan massa material model burung sebesar 1,81 kg. Hal ini sesuai dengan aturan badan regulasi penerbangan yang mengharuskan seluruh komponen harus memenuhi ketahanan struktur terhadap impak burung melalui uji sertifikasi sebelum diizinkan dalam penggunaan operasional. Persyaratan kelaikan terhadap tabrak burung diterbitkan dalam Federal Aviation Regulation (FAR) dan Joint Aviation Regulations (JAR). Windshield atau kanopi pesawat militer yang terbuat dari material brittle (kaca) atau ductile (polikarbonat dan polimetil metakrilat) merupakan komponen utama untuk menjamin keselamatan penerbangan. FAR/JAR subbagian 25.775 mengharuskan struktur tersebut tidak mengalami penetrasi pada kecepatan jelajah ketika mengalami impak dengan burung bermassa $1,8 \mathrm{~kg}$. Kriteria persyaratan untuk leading edge sayap mengharuskan pada saat penetrasi, skin tidak mengalami kerusakan fatal pada bagian front spar atau tanki sehingga penerbangan tetap bisa dilanjutkan dengan aman. Pengujian dilakukan dengan massa burung 1,8 dan $3,6 \mathrm{~kg}$ untuk empennage leading edge pada kecepatan operasional sesuai FAR/JAR subbagian 25.751 dan 25.631. Seluruh gas turbine engines, khususnya turbofan engines harus tahan terhadap burung yang masuk ke dalam engine. Untuk ukuran burung kecil dan sedang, regulasi mensyaratkan kemampuan integritas struktur dan menghasilkan gaya dorong pada level $75 \%$. Persyaratan harus ditunjukkan dengan sertifikasi uji pada keseluruhan engine walaupun manufaktur telah melakukan uji tabrak burung pada fan blades untuk keperluan studi. Engine inlet juga harus mampu menahan beban impak burung 1,8 kg tanpa menyebabkan kerusakan kritikal pada komponen tersebut sesuai dengan ketentuan pada FAR/JAR subbagian 25.751 [6].

Untuk uji sertifikasi pada komponen pesawat, burung asli harus digunakan (biasanya digunakan ayam yang sudah mati). Namun, penggunaan burung asli tidak ideal karena tabrak burung sesungguhnya terjadi di antara sebaran banyak burung. Peraturan sertifikasi hanya menyebutkan massa burung, sedangkan spesies dapat bervariasi, di mana densitas juga bervariasi. Hal inilah yang berpengaruh pada beban impak. Bentuk burung yang tidak beraturan dapat menimbulkan kesulitan untuk menentukan titik serang pada struktur. Untuk alasan ini, banyak perusahaan menggunakan burung pengganti untuk pengujian pra-sertifikasi. Burung pengganti tidak harus seperti burung asli yang terdiri dari daging dan tulang, melainkan harus menghasilkan tekanan yang sama seperti burung asli saat terjadi fenomena tabrak burung [6].

Beberapa tes impak berhubungan dengan material pengganti burung berupa wax, foam, emulsion, beef, rubber, neoprene, dan gelatin telah dilakukan. Dari beberapa jenis material burung pengganti tersebut, ditemukan bahwa material burung pengganti harus memiliki gravitasi spesifik dari air yang dihasilkan sama seperti burung asli. Gelatin dan gelatin berpori dengan gravitasi spesifik dari air yang dihasilkan mempunyai profil sama seperti burung asli dengan tingkat keakuratan tinggi [6]. Gelatin yang digunakan harus mempunyai densitas $\pm 950 \mathrm{~kg} / \mathrm{m}^{3}[9,11]$. Pada pemodelan ini digunakan densitas material pengganti burung sebesar $938 \mathrm{~kg} / \mathrm{m}^{3}$ [12]. 
Material burung dapat dimodelkan dengan material elastic-plastic hydrodynamics [13]. Pada tekanan tinggi, perilaku hydrodynamics pressure-volume dari burung dimodelkan menggunakan tabulasi Equation of State (EOS) untuk menjelaskan periilaku pressure-volume dari burung, di mana energi internal diabaikan.

$$
p=\sum_{k=0}^{3} C_{k}\left(\frac{\rho}{\rho_{0}}-1\right)^{k}
$$

$p$ adalah tekanan, $C_{k}(k=0-3)$ adalah koefisien polinomial, $\rho_{0}$ dan $\rho$ adalah densitas material pada tekanan atmosfer dan saat tumbukan. Gambaran polinomial EOS adalah pendekatan yang terbentuk dari observasi eksperimen perilaku hydrodynamics pressure-volume berbagai jenis material. Ketika $C_{0}=C_{2}=C_{3}=0$, maka hukum dilatasi untuk material elastis dengan modulus bulk $C_{1}$ akan tereduksi [12]. Koefisien polinomial $C_{k}$ pada Persamaan 4. menggambarkan respon impak dari burung pengganti, di mana hal ini sulit diukur secara langsung. Sebagai gantinya, pendekatan yang dilakukan adalah untuk mengkalibrasi koefisien polinomial melalui hasil perbandingan dari simulasi soft impact dan data eksperimen. Oleh karena itu, pendekatan yang dilakukan adalah menggunakan tabulasi EOS Abaqus yang dituliskan secara matematika sebagai berikut:

$$
p=f_{1}\left(\varepsilon_{v o l}\right)+\rho_{0} f_{2}\left(\varepsilon_{v o l}\right) E_{m}
$$

$f_{1}\left(\varepsilon_{v o l}\right)$ dan $f_{2}\left(\varepsilon_{v o l}\right)$ adalah fungsi dari regangan volumetric logaritmik $\varepsilon_{v o l}$, dengan nilai $\varepsilon_{v o l}=\ln \rho_{0} / \rho$, dan $E_{m}$ adalah energi internal per satuan massa. Kontribusi energi internal terhadap tekanan dalam hal ini biasanya diabaikan ketika berhubungan dengan hidrodinamika sehingga $f_{2}\left(\varepsilon_{v o l}\right)=0$ dan $p=f_{1}\left(\varepsilon_{v o l}\right)$. Parameter EOS untuk kasus porositas 0 ditunjukkan pada Tabel 3.3.

Tabel 2. Data material burung [12]

\begin{tabular}{|c|c|c|c|}
\hline $\begin{array}{c}\text { Density } \\
\left(\mathbf{k g} / \mathbf{m}^{\mathbf{3}}\right)\end{array}$ & $\begin{array}{c}\text { Shear } \\
\text { Modulus } \\
\text { (GPa) }\end{array}$ & $\begin{array}{c}\text { Yield } \\
\text { Stress } \\
\mathbf{( M P a )}\end{array}$ & $\begin{array}{c}\text { Hydrostatic } \\
\text { Cut-off } \\
\text { Stress } \\
\text { (MPa) }\end{array}$ \\
\hline 938 & 0,01 & 0,1 & 2,75 \\
\hline
\end{tabular}

\subsection{Kondisi Pembebanan dan Kondisi Batas}

Beban impak diberikan dengan variasi kecepatan awal tumbukan pada burung sebesar 100, 200, dan $300 \mathrm{~m} / \mathrm{s}$. Kondisi batas/tumpuan ditentukan pada setiap sisi ujung pelat dengan tipe fixed.

Tabel 3. EOS [12]

\begin{tabular}{|c|c|c|}
\hline f1 (MPa) & f2 & $\boldsymbol{\varepsilon}_{\text {vol }}$ \\
\hline 0 & 0 & 0 \\
\hline 15.82 & 0 & -0.0073 \\
\hline 32.56 & 0 & -0.0139 \\
\hline 51.17 & 0 & -0.0209 \\
\hline 68.85 & 0 & -0.0280 \\
\hline 87.45 & 0 & -0.0347 \\
\hline 106.06 & 0 & -0.0415 \\
\hline 127.46 & 0 & -0.0487 \\
\hline 147.93 & 0 & -0.0551 \\
\hline 168.40 & 0 & -0.0616 \\
\hline 191.66 & 0 & -0.0681 \\
\hline 213.98 & 0 & -0.0746 \\
\hline 238.17 & 0 & -0.0812 \\
\hline 263.29 & 0 & -0.0878 \\
\hline 289.34 & 0 & -0.0945 \\
\hline 315.39 & 0 & -0.1003 \\
\hline 342.37 & 0 & -0.1071 \\
\hline 370.29 & 0 & -0.1134 \\
\hline 399.13 & 0 & -0.1194 \\
\hline 429.83 & 0 & -0.1258 \\
\hline 460.53 & 0 & -0.1318 \\
\hline 493.09 & 0 & -0.1383 \\
\hline 526.59 & 0 & -0.1444 \\
\hline 561.01 & 0 & -0.1500 \\
\hline 595.43 & 0 & -0.1562 \\
\hline & & \\
\hline
\end{tabular}

\section{HASIL SIMULASI DAN ANALISIS}

Hasil simulasi berupa deformasi dapat dilihat pada Gambar 8. Nilai tekanan diperoleh dengan cara mengambil data gaya kontak antara burung dan pelat tiap saat dan dibagi dengan area kontak tiap saat. Di samping itu, nilai tekanan stagnasi 
diperoleh dengan cara mengintegrasi nilai tekanan pada selang waktu $1 / 3 t_{D}$ hingga $2 / 3 t_{D}$ kemudian dibagi dengan $1 / 3 t_{D}$. Keluaran simulasi tabrak burung berupa kurva tekanan tiap saat yang ditunjukkan pada Gambar 9 sampai 17. Pada kurva tersebut menunjukkan hasil yang hampir sama, yaitu tekanan Hugoniot di awal impak dan tekanan stagnasi setelahnya. Hasil tekanan Hugoniot dan stagnasi dirangkum pada Tabel 4 dan Tabel 5.

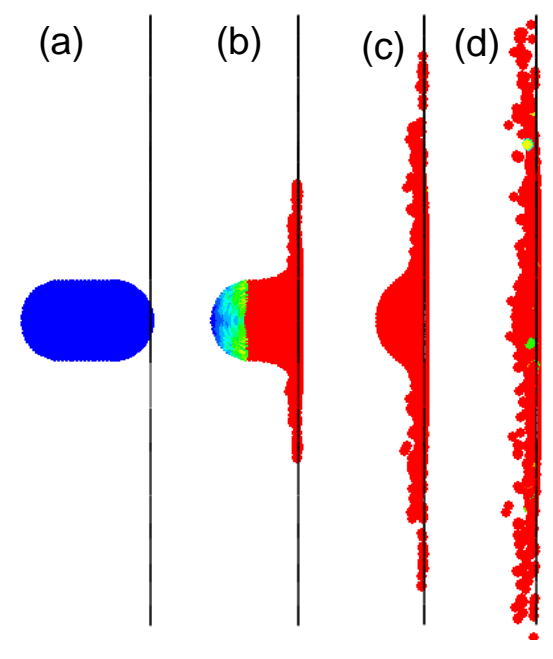

Gambar 8. Pola deformasi burung rasio $L / D=$ 1.7 pada kecepatan $200 \mathrm{~m} / \mathrm{s}$ tiap waktu: (a) $0 \mathrm{~s}$, (b) $3.5 \mathrm{e}-04$, (c) $6.9 \mathrm{e}-04$, dan (d) $14 \mathrm{e}-04$.

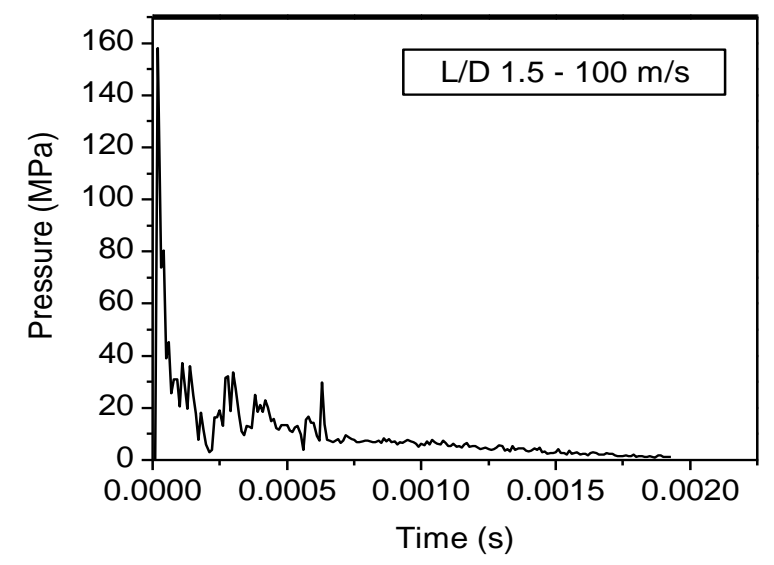

Gambar 9. Tekanan impak terhadap waktu untuk burung rasio $L / D=1.5$ pada kecepatan $100 \mathrm{~m} / \mathrm{s}$.

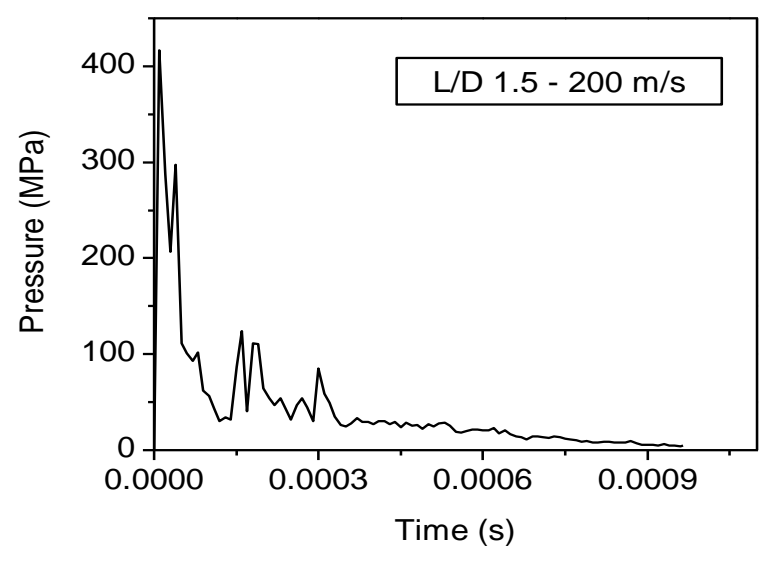

Gambar 10. Tekanan impak terhadap waktu untuk burung rasio $\mathrm{L} / \mathrm{D}=1.5$ pada kecepatan $200 \mathrm{~m} / \mathrm{s}$.

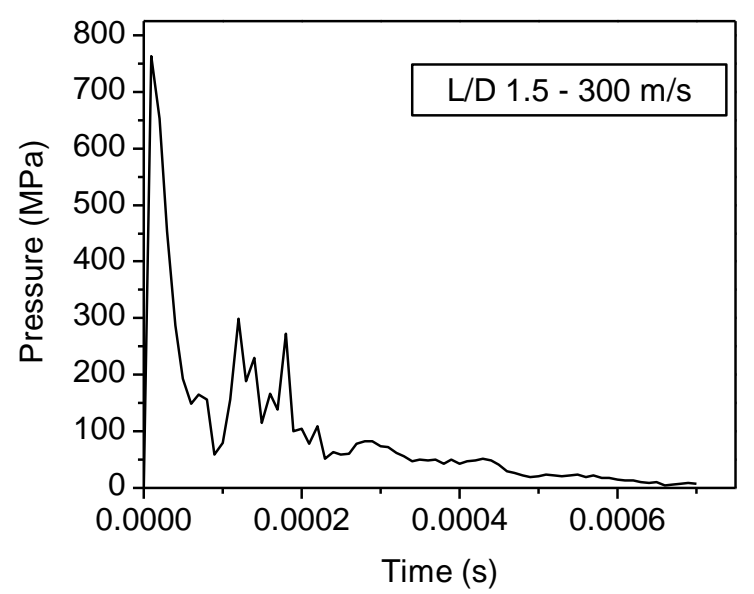

Gambar 11. Tekanan impak terhadap waktu untuk burung rasio $\mathrm{L} / \mathrm{D}=1.5$ pada kecepatan $300 \mathrm{~m} / \mathrm{s}$.

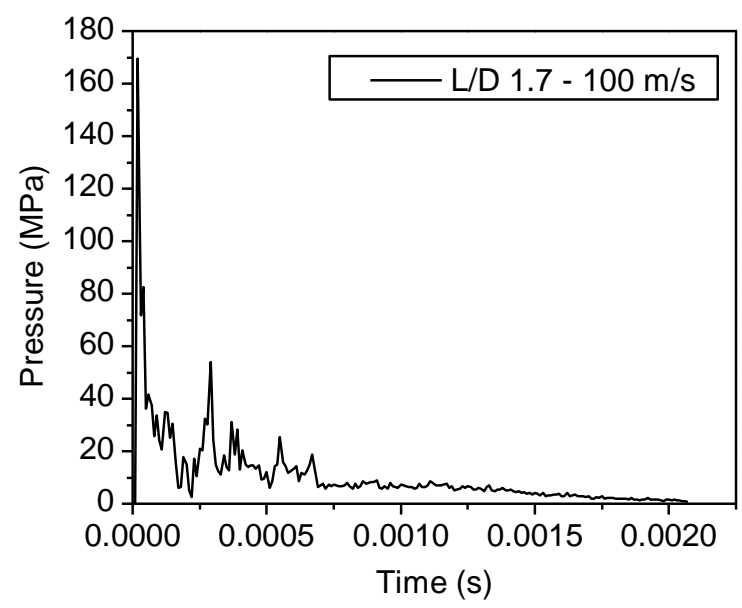

Gambar 12. Tekanan impak terhadap waktu untuk burung rasio $L / D=1.7$ pada kecepatan $100 \mathrm{~m} / \mathrm{s}$. 


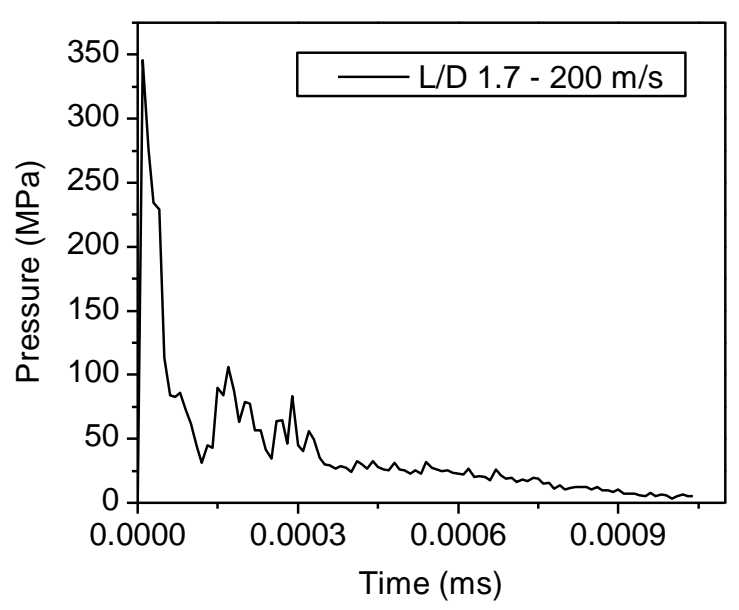

Gambar 13. Tekanan impak terhadap waktu untuk burung rasio $L / D=1.7$ pada kecepatan $200 \mathrm{~m} / \mathrm{s}$.

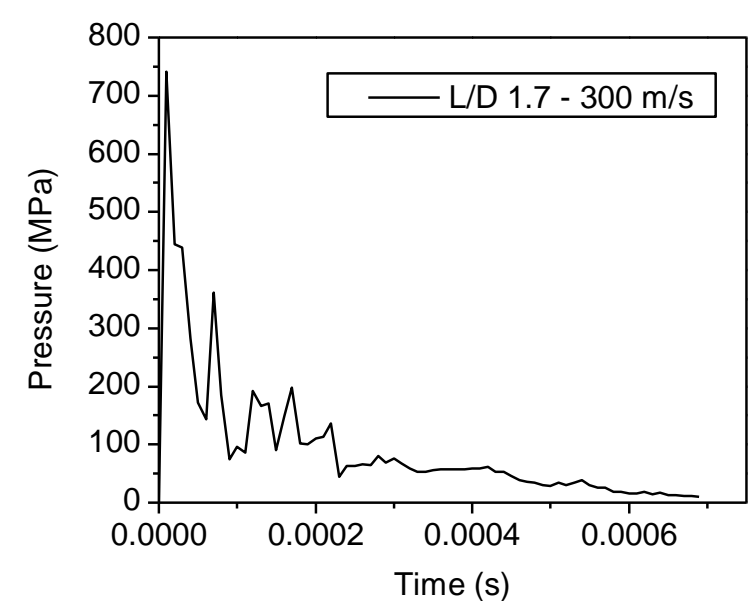

Gambar 14. Tekanan impak terhadap waktu untuk burung rasio $\mathrm{L} / \mathrm{D}=1.7$ pada kecepatan $300 \mathrm{~m} / \mathrm{s}$.

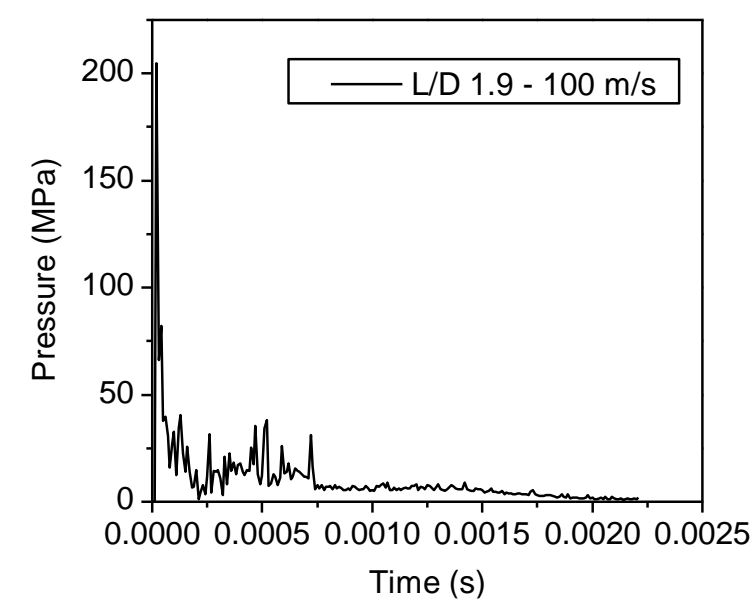

Gambar 15. Tekanan impak terhadap waktu untuk burung rasio $\mathrm{L} / \mathrm{D}=1.9$ pada kecepatan $100 \mathrm{~m} / \mathrm{s}$.

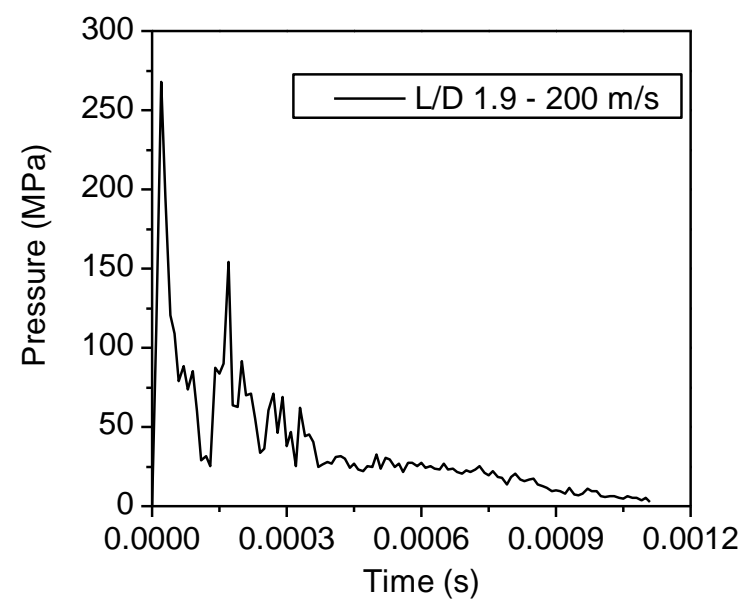

Gambar 16. Tekanan impak terhadap waktu untuk burung rasio $\mathrm{L} / \mathrm{D}=1.9$ pada kecepatan $200 \mathrm{~m} / \mathrm{s}$.

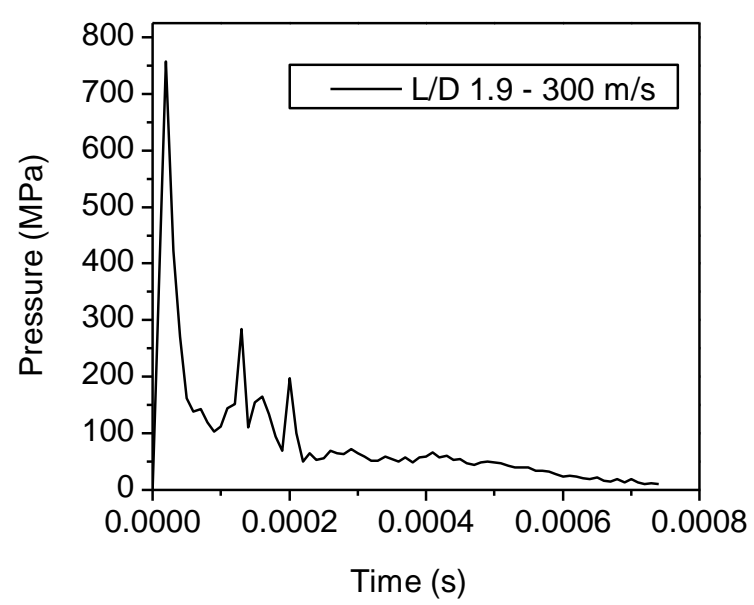

Gambar 17. Tekanan impak terhadap waktu untuk burung rasio $\mathrm{L} / \mathrm{D}=1.9$ pada kecepatan $300 \mathrm{~m} / \mathrm{s}$.

Tabel 4. Hasil Tekanan Hugoniot

\begin{tabular}{|c|c|c|c|}
\hline \multirow{2}{*}{ L/D } & \multicolumn{3}{|c|}{ Tekanan Hugoniot } \\
\cline { 2 - 4 } & $\mathbf{1 0 0} \mathbf{~} / \mathbf{s}$ & $\mathbf{2 0 0} \mathbf{~ m} / \mathbf{s}$ & $\mathbf{3 0 0} \mathbf{~} / \mathbf{s}$ \\
\hline $\mathbf{1 . 5}$ & 158.115 & 416.572 & 762.531 \\
\hline $\mathbf{1 . 7}$ & 169.669 & 345.516 & 740.713 \\
\hline $\mathbf{1 . 9}$ & 204.819 & 267.949 & 757.376 \\
\hline Rata-rata & 177.534 & 343,346 & 753,54 \\
\hline
\end{tabular}

Tabel 5. Hasil Tekanan Stagnasi

\begin{tabular}{|c|c|c|c|}
\hline \multirow{2}{*}{ L/D } & \multicolumn{3}{|c|}{ Tekanan Hugoniot } \\
\cline { 2 - 4 } & $\mathbf{1 0 0} \mathbf{~} / \mathbf{s}$ & $\mathbf{2 0 0} \mathbf{~ m} / \mathbf{s}$ & $\mathbf{3 0 0} \mathbf{~} / \mathbf{s}$ \\
\hline $\mathbf{1 . 5}$ & 6.2 & 24.4 & 53.2 \\
\hline $\mathbf{1 . 7}$ & 6.63 & 25.2 & 59.7 \\
\hline $\mathbf{1 . 9}$ & 5.92 & 23 & 55.4 \\
\hline Rata-rata & 6,25 & 24,2 & 56,1 \\
\hline
\end{tabular}




\section{KESIMPULAN}

Berdasarkan hasil simulasi numerik dengan variasi rasio $L / D$, diperoleh bahwa nilai tekanan Hugoniot jauh lebih tinggi sekitar 14-25 kali lipat tekanan stagnasi pada $\mathrm{L} / \mathrm{D}=1.5 ; 12-25$ kali pada $\mathrm{L} / \mathrm{D}=1,7$; dan 11-34 kali pada $L / D=1,9$. Tekanan Hugoniot menunjukkan nilai yang meningkat dari L/D 1.5 sampai 1.9 pada kecepatan 100 m/s. Namun, untuk tekanan Hugoniot pada kecepatan $200 \mathrm{~m} / \mathrm{s}$ menunjukkan nilai yang menurun dari L/D 1.5 sampai 1.9. Di sisi lain, tekanan stagnasi rasio L/D 1.9 lebih rendah dibandingkan L/D 1.5 dan 1.7 pada kecepatan impak 100 dan 200 m/s.

\section{Ucapan Terima Kasih.}

Penelitian ini didukung oleh Unsurya berdasarkan Hibah Penelitian Internal di Tahun Akademik 2019-2020.

\section{DAFTAR REFERENSI}

1. Blokpoel, H., Bird Hazards To Aircraft. Clarke. 1976.

2. Thorpe, J., Fatalities and Destroyed Civil Aircraft Due To Bird Strikes, 1912-2002. In: International Bird Strike Committee, 26th Meeting, Warsaw, Poland. 2003.

3. Allan, J. R., The costs of bird strikes and bird strike prevention. In Human conflicts with wildlife: Econonomic considerations (pp. 147-153). Lincoln, NE: USDA National Wildlife Research Center Symposia. 2000.

4. Grimaldi, A., SPH high velocity impact analysis - A birdstrike windshield application. Dissertation, Department of Aerospace Engineering, University of Naples Federico II. 2011.
5. Allan, J. R., \& Orosz, A. P., , The costs of birdstrikes to commercial aviation. In Bird Strike Committee - USA/Canada, third joint annual meeting (p.2). Calgary, AB. 2001.

6. Sebastian Heimbs, Bird Strike Analysis in Aircraft Engineering: An Overview. Advances in Mechanical Engineering Research, Vol 3. Nova Science Publishers, Inc. 2011.

7. Yuniarti, E., Hendrajaja, S.S., Sitompul, Sahril A., , Analisis Numerik Pengaruh Geometri Burung Berbentuk Capsule Terhadap Tekanan Impak Pada Kasus Bird Strike, Jurnal Teknologi Kedirgantaraan ISSN 2528-2778, Vol. 3 No.2 Juli 2018, hal. 7-12. 2018.

8. Yuniarti, E., Sitompul, Sahril A., , Effect Of Flat And Hemispherically Ended Cylinder Bird Model With Finite Element Modelling Of Bird Strike, Jurnal Teknologi Dirgantara LAPAN ISSN 1412-8063, Vol 17 No. 1 hal. 41-56, Juli 2019.

9. J.S. Wilbeck, J.P. Barber, Impact bird loading, The Shock and Vibration Bulletin 48, p. 115-122. 1978.

10. Blair, A., Aeroengine Fan Blade Desain Accounting For Bird Strike, Thesis, Department Aeronautical and Industrial Engineering, The University of Toronto. 2008.

11. Airoldi, A. dan Cacchione, B., Modelling of Impact Forces and Pressures in Lagrangian Bird Strike Analyses, International Journal of Impact Engineering, 32, pp. 1651-1677. 2006.

12. SIMULIA, A strategy for bird strike simulations using Abaqus/Explicit. Dassault Sytemes. 2018.

13. Hedayati, R., \& Sadighi, M., Bird Strike: An Experiment, Theretical and Numerical Investigations, ISBN 978-756501-939-5, Woodhead Publishing. 2016. 